\title{
John T. Cunningham: An Appreciation
}

Mark Lender

Abstract: A friend and colleague pays tribute to John T. Cunningham, the indefatigable chronicler of New Jersey history.

John T. Cunningham died in Morristown on 7 June 2012, after 96 full years. He was the most prolific and popular author ever to write on New Jersey history, and he was as public-spirited a citizen as the Garden State ever had.

Like all of us who knew him, I learned of his passing with sincere regret. But at the same time, it brought back so many memories of a man who was at once a friend, colleague, and sometime mentor. Anyone working in New Jersey history knew who John Cunningham was, although as a graduate student at Rutgers I only knew him through his work. We met for the first time, I believe, in 1975, just as the Bicentennial celebrations were reaching full steam. I had just finished my graduate program, and was invited to speak at a local historical society - I forget where - and was pleased to learn that Cunningham would be there as well. I remember looking forward to finally meeting the man I'd heard so much about, although the evening turned out to be something of an unanticipated learning experience. He delivered a polished presentation on patriot leaders in New Jersey that was both erudite and humorous; he connected easily with the audience, and they loved it.

I then followed him to the lectern and put half the audience to sleep with a chunk of my dissertation on New Jersey's Continental soldiers. I learned a lesson that evening: John T. Cunningham was a tough act to follow. Over the years, we probably shared a podium a dozen or more times, and, always remembering that first night so long ago, whenever I could, I tried to speak first. John was a real pro. 
I got to know John well over the years, and early on I asked how he had developed such a passion for state history. As he explained it to me (somewhat wryly), his interest in the history of his native state began in his days with the Newark News. The News was a great paper in its day, and John was proud to be a reporter. "In those days," he wrote, "being a reporter for the Newark News was as fine a profession as a young person could desire .... Being introduced as a staff member of the News was tantamount to acceptance anywhere in New Jersey, for this was a paper with integrity, thoroughness and competency." Some of his assignments involved putting a New Jersey twist on national and international stories: If there was an earthquake or disaster somewhere in the world, his job was to find someone from New Jersey who was there- or someone who knew someone who was there - or someone who may have heard of someone who was there - and then write it up for New Jersey readers who otherwise might have cared less about the earthquake (or the disaster).

He learned about New Jersey in depth, and he learned that people were actually interested in its affairs and its history. And he picked up traits at the News that would mark his own writing for the rest of his life: "integrity, thoroughness and competency."

He was a terrific historian. His interests ranged across subjects and eras, and his bibliography is ... well . . .huge. He wrote some fifty books, including a wonderful history of railroading in New Jersey, a magisterial history of Newark, some truly fascinating work on the New Jersey environment, and, in his last book, what now stands as the standard work on the patriot army's grueling encampments at Morristown. A great point of pride with John was his ability to write it all up so that non-specialists could appreciate it. John always stressed that if you wrote only for other historians, you just weren't doing your job as a good author, and that any point you were trying to make would seldom reach much of a readership. I've tried to keep that in mind.

But having said this, John was never simply a "popular" historian. In fact, no one was a more capable researcher or more comfortable with original sources, or better at putting a new interpretation on well-trodden historical ground. There are plenty of examples of this in John's work, but let me cite just one. In the mid-1980s, in an article 
on the history of sports, he noted that too often the subject was a matter of batting averages and profiles of individual athletes. Instead, John insisted that "sports are a means to understand the elusive American character."2 From there on, the article followed just that thread. It was a great read (what else?), and original in its perspectives and conclusions. That is what good historians do.

If John wrote for a broad public, he gave his time and counsel to the public as well. He served as chairman of the New Jersey Historical Commission and president of the New Jersey Historical Society, he spoke before audiences across the state, and government agencies and regional historical and civic organizations gained from his advice. He was truly a New Jersey cultural resource. Thankfully, the state acknowledged as much, and his honors were well deserved. In fact, I don't believe I've met anyone with as many doctoral degrees honoris causa. I may not know of all of them, but I can account for degrees from his alma mater, Drew University, as well as from Fairleigh Dickinson, Rutgers, Kean, Montclair State, and Monmouth Universities, and from Caldwell College. Wall space in John's office must have been at a premium.

John was generous with his advice to others of us working and teaching in state history. It was John, along with Richard P. McCormick and Clement Price, who persuaded me to serve as editor of New Jersey History for some ten years. He also coached me through a number of projects in my younger days, and those projects were the better for it. At one point, I showed him an offer I was going to submit to a company for a contract history. He read it and laughed. Rather, he LAUGHED. Double your bill, he said, they'll agree. I did, and they did. (Thanks, John!) Thanks as well for helping those of us in the classroom: I still assign one of John's textbooks when I teach New Jersey History. I could go on, and any number of us in the field could as well.

There is a final thought, and not a small one: John Cunningham was a gentleman, and there's all too few of them left. I'll miss him. A lot of us will. 
${ }^{1}$ John T. Cunningham, "Foreword" to Douglas Eldridge, "The Rise and Fall of the Newark News: A Personal Perspective," New Jersey History 104 (1986): 38.

${ }^{2}$ John T. Cunningham, “Games People Played: Sports in New Jersey History,” New Jersey History 103 (1985): 1 . 